\title{
Evidence of Polar Mesosphere Summer Echoes Observed by SuperDARN SANAE HF Radar in Antarctica
}

\author{
Olakunle Ogunjobi ${ }^{1, *}$, Venkataraman Sivakumar ${ }^{1}$, Judy Ann Elizabeth Stephenson ${ }^{1}$, and \\ William Tafon Sivla ${ }^{2}$ \\ ${ }^{1}$ School of Chemistry and Physics, University of KwaZulu-Natal, Durban, South Africa \\ ${ }^{2}$ Department of Physics, Benue State University, Makurdi, Nigeria
}

Received 20 March 2014, revised 5 March 2015, accepted 6 March 2015

\begin{abstract}
We report on the polar mesosphere summer echoes (PMSE) occurrence probability over SANAE (South African National Antarctic Expedition) IV, for the first time. A matching coincidence method is described and implemented for PMSE extraction from SuperDARN (Super Dual Auroral Radar Network) HF radar. Several SuperDARN-PMSE characteristics are studied during the summer period from years 2005 - 2007. The seasonal and interannual SuperDARN-PMSE variations in relation to the mesospheric neutral winds are studied and presented in this paper. The occurrence probability of SuperDARNPMSE on the day-to-day scale show, predominantly, diurnal variation, with a broader peak between 12 - 14 LT and distinct minimum of $22 \mathrm{LT}$. The SuperDARN-PMSE occurrence probability rate is high in the summer solstice. Seasonal variations show a connection between the SuperDARN-PMSE occurrence probability rate and mesospheric temperature from SABER (Sounding of the Atmosphere using Broadband Emission Radiometry). The seasonal trend for both meridional and zonal winds is very stable year-to-year. Analysis of the neutral wind variations indicates the importance of pole-to-pole circulations in SuperDARN-PMSE generation.
\end{abstract}

Key words: PMSE, SANAE IV, SuperDARN radar, Neutral winds, MLT Temperatures

Citation: Ogunjobi, O., V. Sivakumar, J. A. E. Stephenson, and W. T. Sivla, 2015: Evidence of polar mesosphere summer echoes observed by SuperDARN SANAE HF radar in Antarctica. Terr. Atmos. Ocean. Sci., 26, 431-440, doi: 10.3319/TAO.2015.03.06.01(AA)

\section{INTRODUCTION}

It is generally accepted that during the polar summer time the charged ice aerosol particle and mesospheric neutral air turbulence interactions result in strong radar backscatter echoes within $90-100 \mathrm{~km}$ altitudes. These echoes are referred to as polar mesosphere summer echoes (PMSE). The PMSE are closely linked to visible ice particles below 90 $\mathrm{km}$ altitude, known as noctilucent clouds (NLC) (Cho and Röttger 1997; Rapp and Lübken 2004). The NLC and PMSE phenomena arise from the formation of ice particles in the low polar summer mesopause temperatures. These layered phenomena are perhaps, good indicators of anthropogenic effects on climate change. It has been suggested that NLC and PMSE are comparatively different in their occurrence mechanisms. NLC indicates the presence of thin water-ice particles, formed at low summer mesopause temperature,

\footnotetext{
* Corresponding author

E-mail: olakunle.ukzn@gmail.com
}

ranging from 120 - $150 \mathrm{~K}$ (Hervig et al. 2009). An additional precondition for PMSE occurrence is the presence of charged ice particles on the Bragg's wavelength scale. It was broadly noticed by earlier researchers that PMSE occurrence is due to the combination of atmospheric turbulence produced by gravity waves and electrically charged ice particles within the mesosphere (see, Rapp and Lübken 2004). Therefore, PMSE represent, partly, a mesospheric event that can be used to study the neutral atmosphere and mesospheric dynamics. PMSE observations have been found to support understanding the temperature modification between the Arctic and Antarctic mesopause regions (Huaman and Balsley 1999). PMSE observations with radar have the advantage of being continuous, unlike NLC which depends on the observer and weather conditions (Rapp and Lübken 2004).

Over the past 3 decades coherent Very-High-Frequency (VHF) radars have been found to be a useful tool 
in studying PMSE dynamics in the Arctic regions (Ecklund and Balsley 1981; Palmer et al. 1996; Hoffmann et al. 1999; Rapp and Lübken 2004). The PMSE characteristics and occurrence rates, from different instruments are still expected in this field. There has been a notable absence of sufficient measurements in the Southern hemisphere. The few coherent VHF observations from the Antarctic indicate irregular PMSE distribution due to its complex mesospheric thermal phenomena. For instance, some studies have observed PMSE in the VHF band in correlation and anti-correlation to temperature, neutral winds, particle precipitation, cosmic noise absorption and gravity waves (Cho et al. 1992; Kirkwood 1993; Röttger 1994; Hoffmann et al. 1999; Klostermeyer 1999; Liu et al. 2002; Klekociuk et al. 2008). These complex phenomena range from periodic and episodic perturbations to those on a global scale.

There are ongoing efforts to complement the VHF PMSE observations with coherent HF Super Dual Auroral Radar Network (SuperDARN), e.g., Hosokawa et al. (2004, 2005); Ogawa et al. (2004); Liu et al. (2013). Hosokawa et al. (2005), for example, developed an algorithm for extracting PMSE from SuperDARN Syowa HF radar in the Southern hemisphere and Iceland in the Northern hemisphere. This algorithm was employed with a careful consideration of other overlapping echoes such as meteor trails and sporadic E-region echoes in the PMSE range. Hosokawa et al. (2005)'s results showed weaker interhemispheric asymmetry in PMSE occurrence than earlier predictions based on VHF radar observations. Furthermore, Hosokawa et al. (2005) observed, predominantly diurnal PMSE variation. A similar algorithm was also employed by Liu et al. (2013) for extracting PMSE from SuperDARN Zhongshan HF radar $\left(69.41^{\circ} \mathrm{S}, 76.41^{\circ} \mathrm{E}\right)$. The results from Zhongshan station indicate semidiurnal PMSE event variation. Liu et al. (2013) suggested from their observation that the auroral particle precipitation might be a major contributor to the semidiurnal PMSE occurrence. Therefore, understanding the Southern hemisphere PMSE variability dynamics requires evidence and characteristics from different locations, during different seasons (Morris et al. 2004; Jarvis et al. 2005). During maximum solar activity, energetic particle precipitation and the levels of Extreme ultraviolent (EUV) radiation could be high. It is expected that solar quiet time electrodynamics in the mesospheric region will be driven, mainly, by gravity waves, tides, and upward propagating planetary waves (Richardson et al. 2001).

This paper presents first time observations of possible PMSE by a SuperDARN HF radar at SANAE (South African National Antarctic Expedition) IV $\left(71.68^{\circ} \mathrm{S}, 2.85^{\circ} \mathrm{W}\right)$, hereafter referred to as SuperDARN-PMSE. The SuperDARN-PMSE occurrence probabilities for the summer periods for years 2005 - 2007, solar minimum, were analyzed. The seasonal, diurnal and interannual variations were examined. The relationship between seasonal PMSE occurrence variation rate and mesospheric neutral winds were examined. We discuss the possible temperature changes in relation to SuperDARN-PMSE probability peaks.

\section{INSTRUMENTATION AND DATA ANALYSIS}

\subsection{SuperDARN Data}

Data from the SuperDARN SANAE IV radar is employed in this study. This radar uses the frequency band between 8 - $20 \mathrm{MHz}$. The antenna array consists of 16 horizontally polarized log-periodic antennae, operated as a phased array, having $170^{\circ}$ bore-site. SANAE IV radar is technically and operationally similar to other 32 SuperDARN radars located at polar and midlatitudes. The SuperDARN radars at different locations use the same (common) scanning parameters for $50 \%$ of the entire instrument operational time (Greenwald et al. 1995; Hosokawa et al. 2005; Lester 2013). In common time operation the SuperDARN radar beam is, sequentially scanned from beam $0-15$ across its 75 range gates with a step in azimuth of $3.33^{\circ}$, a scan repeat time of 2 minutes, range resolution of $45 \mathrm{~km}$ and a peak power of about $10 \mathrm{~kW}$. The radar beam width $(3 \mathrm{~dB})$ of $\leq 35^{\circ}$ allows backscatter echo detection. The return echoes from the beams are integrated over $7 \mathrm{~s}$. Note that the radar data used in the present analysis were obtained during common time operation periods.

The backscatter delays at the nearest range gate ( 0 gate) were set to $1200 \mu$ s pulse length, which is equivalent to $180 \mathrm{~km}$. The subsequent pulse length is set to $300 \mu$ s, equivalent to a gate length of $45 \mathrm{~km}$. In the SuperDARN configuration the maximum radar sensitivity is about $3555 \mathrm{~km}$, with field of view (FOV) comprising 1200 cells. In this study the near range gate is taken from $0-1$ which corresponds to a distance of $180-225 \mathrm{~km}$. The near range gates correspond to mesospheric altitudes. The FOV of SANAE IV radar, projected in geomagnetic coordinates, is presented in Fig. 1. The FOV shows that SuperDARN SANAE IV radar is located at the sub-auroral location suitable for observations of $\mathrm{HF}$ backscatters such as PMSE event. The SuperDARN radars targets are coherent. The oblique sounding technique of $\mathrm{Su}-$ perDARN is such that it can detect backscatters such as meteor trails, sporadic E-region echoes and PMSE simultaneously within the near range gates. A systematic approach is required to isolate PMSE from other contaminating echoes. According to Hosokawa et al. (2005) only PMSE has been judged to be present in the near gate if both the spectral width and Doppler velocity measurements are less than $50 \mathrm{~m} \mathrm{~s}^{-1}$ and the power is greater than $6 \mathrm{~dB}$.

Figure 2 depicts the typical instances of these three forms of backscatter features, as obtained from beam number 12. In Fig. 2 (left panel) the top to bottom panels are gate versus time plots of backscatter power, spectral width and Doppler velocity observed on 21 December 2005. During the summer solstice period backscatter echoes were found 
higher compared to 21 April 2005 in Fig. 2 (right panel). Perhaps the PMSE contributed to the high rate of backscatters detected in the summer solstice.

\subsubsection{SuperDARN Meteor Wind}

SuperDARN meteor trail observations at $94 \mathrm{~km}$ height are associated with drift in neutral wind velocities which is useful in studying meridional and zonal circulation trends. Although SuperDARN radar is not planned specifically for wind observations, it can be used to track neutral wind variations at mesopause altitude. A detailed description of tracking neutral winds using SuperDARN radar can be found elsewhere (Hussey et al. 2000; Chisham et al. 2007). It should be noted that winds are altitude dependent and thus, neutral wind meteor radar observations can only be qualitative (Yukimatu and Tsutumi 2002, 2003).

\subsection{Riometer Data}

We used the ionospheric absorption measurements from the ground-based riometer located at SANAE IV in this study. Riometers respond to the integrated absorption of cosmic ray noise through the ionosphere (Wilson and Stoker 2002; Hargreaves and Friedrich 2003), usually around $90 \mathrm{~km}$ altitude (Ogunjobi et al. 2014b). The E-region irregularities due to geomagnetic disturbances can result in aurora (Greenwald et al. 1995; Liu et al. 2013; Zhang et al. 2013). On the other hand the visible aurora is an effect of precipitating energetic particles interacting with the Earth's magnetic field. The interactions can create steep electron density gradients and by extension cause cosmic radio noise at the mesopause region (e.g., Wu et al. 2013; Ogunjobi et al. 2014a). The riometer data may permit us to, indirectly, examine the possible dependence of SuperDARN-PMSE on ionospheric echoes produced by energetic particle precipitation.

\subsection{Thermosphere Ionosphere Mesosphere Energetic and Dynamics/Sounding of the Atmosphere Using Broadband Emission Radiometry Data}

In order to examine any potential connection between SuperDARN-PMSE and mesospheric temperature, we obtained vertical temperature data from TIMED/SABER (Thermosphere Ionosphere Mesosphere Energetic and Dynamics/Sounding of the Atmosphere using Broadband Emission Radiometry). The TIMED satellite was launched on 7 December 2001, to a $625 \mathrm{~km}$ circular polar orbit with about $74.1^{\circ}$ inclination and an orbital period of $102 \mathrm{~min}$ utes. By step scanning the atmosphere limb, SABER, which

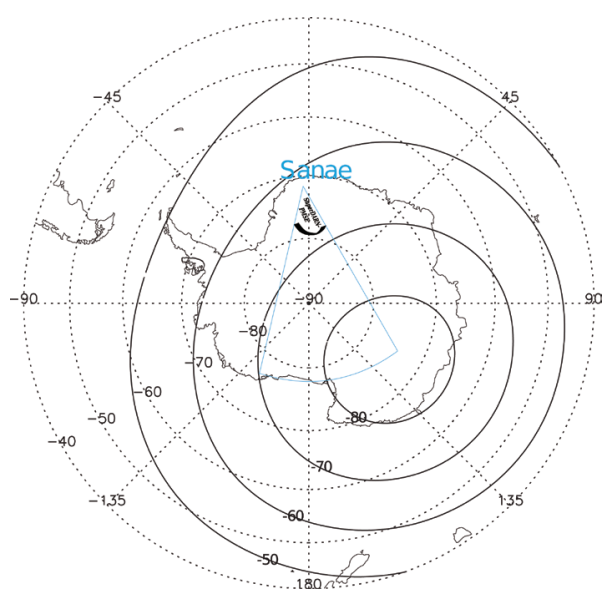

Fig. 1. Map showing the SANAE radar field of view (blue line) projected on a geographic (dash lines) and geomagnetic (solid lines) coordinates. The coordinates $\mathrm{x}$ and $\mathrm{y}$ axes are based on geographic $90^{\circ}$ and $0^{\circ}$ directions. The calligraphic shows relative region of SuperDARNPMSE.
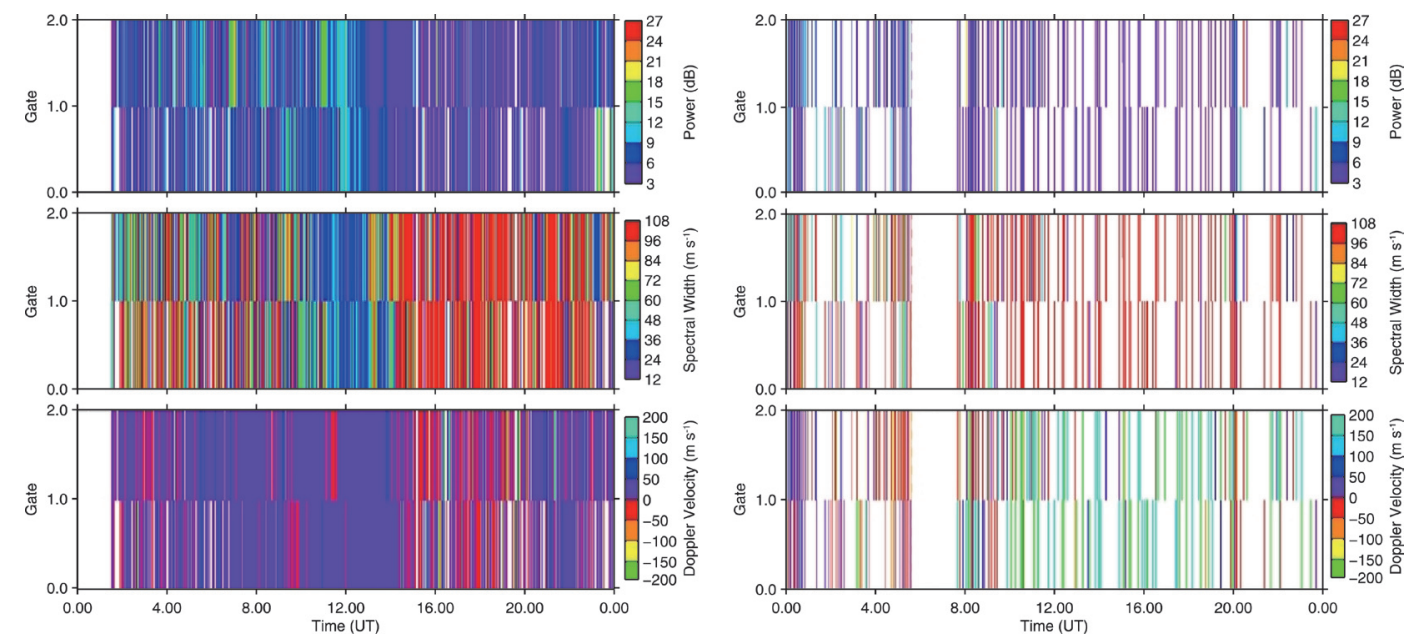

Fig. 2. SuperDARN SANAE IV scatter plot of backscatter power, spectral width and Doppler velocity. Beam 12 near range gates on 21 December 2005 (left panel) and 21 April 2005 (right panel). 
is one of the four instruments on-board the TIMED satellite, measures the height profile of neutral temperature. The vertical temperature measurements in the vicinity of SANAE IV were obtained. Details on how SABER temperature is retrieved will be discussed later. April - September is referred to as winter and October - March as summer to achieve qualitative estimate in this study.

\section{RESULTS AND DISCUSSION}

\subsection{SuperDARN-PMSE Characteristics}

SuperDARN-PMSE is judged present if certain conditions are met. In order to quantitatively eliminate other overlapping echoes, a SuperDARN-PMSE event is selected when the backscatter power is above $6 \mathrm{~dB}$ and the Doppler velocity and spectral width are below $50 \mathrm{~m} \mathrm{~s}^{-1}$. The occurrence rate was computed from the near range and then calculated in 10 minutes intervals for the period under study.

Figure 3 shows the SuperDARN-PMSE occurrence probability rate prior and after the Antarctic summer seasons of 2005/2006. The SuperDARN-PMSE occurrence rates start to rise near November 2005. Thereafter it increases steadily until the end of January 2006. The SuperDARNPMSE occurrence probability rate shows maximum peak $(50 \%)$ near the summer solstice. Our seasonal variation is similar to previous observations from $\mathrm{HF}$ radar. Using $\mathrm{Su}-$ perDARN Iceland and Syowa HF radar, Hosokawa et al. (2005) observed a sudden increase in PMSE at the beginning of the summer season and a gradual decay toward the end of January. Similar to Hoffmann et al. (1999) and Hosokawa et al. (2005), we observed a predominant diurnal variation in SuperDARN-PMSE over SANAE IV. These statistical results are also similar to previous studies in VHF bands despite the differences in radar location, time and experimental setup.

It should be noted that the determination of near range contamination depends on the specific location and radar characteristics which might vary slightly from radar to radar. For instance, Liu et al. (2013) found that at Zhongshan HF radar station (being directly under the auroral oval), there was a maximum PMSE peak near local midnight and a secondary PMSE peak few hours after the local noon. They attributed this semidiurnal variation to role of precipitating energetic particles. They also showed that the aspect angle condition for ionospheric echoes could not have been satisfied at gate $0-2$. Although we have seen a similar trend for local noon we cannot find any tendency for the midnight SuperDARN-PMSE peak. This could be, perhaps due to the SANAE IV location at the sub-auroral oval location. We prefer to be cautious with our conclusion regarding diurnal SuperDARN-PMSE occurrence probability rate here because the atmospheric features such as planetary waves and tides may cause the PMSE diurnal trend to require a longer time to be better observed.
In reference to the above limitation we studied the subsequent summer for any significant inter annual variation over our region of interest. Figure 4 presents SuperDARNPMSE occurrence for 2006/2007 over SANAE IV. There is no significant difference in inter annual SuperDARN-PMSE variations. Similar to the preceding year (Fig. 3), the maximum occurrence probability rate is $50 \%$ for SANAE IV, around the same summer solstice. The inter-annual similarity in the occurrence probability rate over SANAE IV may, perhaps, be as a consequence of persistent situation during the declining phase of a solar cycle. This observation agrees with the combine SuperDARN-PMSE statistics shown in Fig. 5. The highest distribution is shifted towards the summer solstice. This shows that SuperDARN-PMSE variations, indeed, follows the initial conditions (for instance, Ogawa et al. 2004).

The evidences for insignificant inter annual variation encourages us to combine diurnal SuperDARN-PMSE rates for both summers. The occurrence probability rates were combined in a vector addition to yield the hourly variation. In this method for each hour of the day a mean was taken through the entire period under study. In other words we obtained a combined diurnal mean rate for both the 2005/2006 and 2006/2007 summer months.

In Fig. 6 the diurnal variations in the SuperDARNPMSE occurrence rate are characterized by the highest peaks around $12 \mathrm{LT}$ and minimal near $22 \mathrm{LT}$. The broad maximum obtained at $11-13$ LT is also similar to previous VHF and HF observations at several high latitude locations. Similar to other radar study by Hoffmann et al. (1999) and Hosokawa et al. (2005), a diurnal maximum occurrence was around 13 LT and minimum occurrence at about $21 \mathrm{LT}$. This is in sharp contrast with the study of Liu et al. (2013), which noted a semidiurnal variation of PMSE occurrence at Zhongshan station. Liu et al. (2013) observed a maximum PMSE occurrence near $0 \mathrm{LT}$ and a secondary maximum near $13 \mathrm{LT}$, while a distinct minimum was seen near 19 LT. Balsley et al. (1983); Morris et al. (2007); Latteck et al. (2008) had reported earlier that the PMSE occurrence has a broad maximum at $1-2 \mathrm{~h}$ after the local noon and that the secondary peak usually appears around the local midnight. In this study, we did not observe such semidiurnal characteristics.

Over the past 3 decades, PMSE observations showed maximal and minimal with different instruments. Some discrepancies (usually $\pm 2 \mathrm{~h}$ ) existed in the maxima and minima temporal position determinations. One possible reason for these discrepancies is the sidereal time of the day, which differs from one location to another. In the case of VHF radars, the volume reflectivity and signal to noise ratio thresholds may result in some temporal discrepancies (Smirnova et al. 2010). Although the existence of the diurnal and semidiurnal variations has been widely reported, the causative mechanism is yet to be completely understood. We observe broader SuperDARN-PMSE maximum at noon and a distinct 
minimum at midnight. Furthermore, the discrepancies in terms of semidiurnal variations could be that, SuperDARNPMSE occurrence also depends on numerous factors such as planetary waves. This will be the subject for a future study.

\subsection{SuperDARN-PMSE Occurrence in Relation to Cosmic Noise Absorption}

In order to check the relationship between energetic particle precipitation and SuperDARN-PMSE occurrence probability rate, we examined the correlation between the cosmic noise absorption and SuperDARN-PMSE variations from 1 October to 31 March. Any absorption $\geq 1 \mathrm{~dB}$ is regarded as an extra ordinary absorption (Ogunjobi et al. 2014a, b). For more clarity we grouped the absorption measurements into three thresholds: $0.0-0.4 \mathrm{~dB}$ (less absorption), $0.5-0.9 \mathrm{~dB}$ (moderate absorption), and $\geq 1 \mathrm{~dB}$ (extra ordinary absorption) as shown in Fig. 7. In the figures (Figs. 7 a, b, and c), we observe insignificant changes in the SuperDARN- PMSE occurrence rates with higher absorption level. In other words,

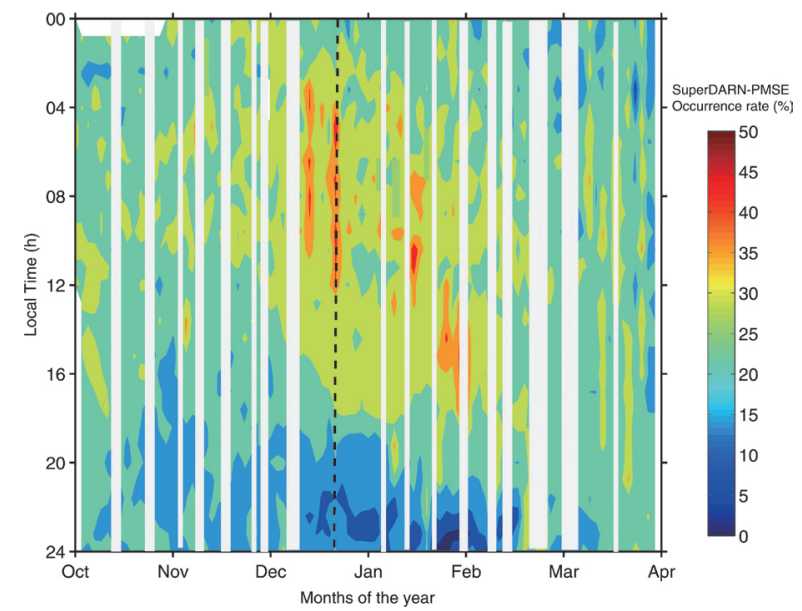

Fig. 3. SuperDARN-PMSE occurrence probability rate at SANAE IV during October 2005 to April 2006 summer season. The vertical dash line indicates December solstice.

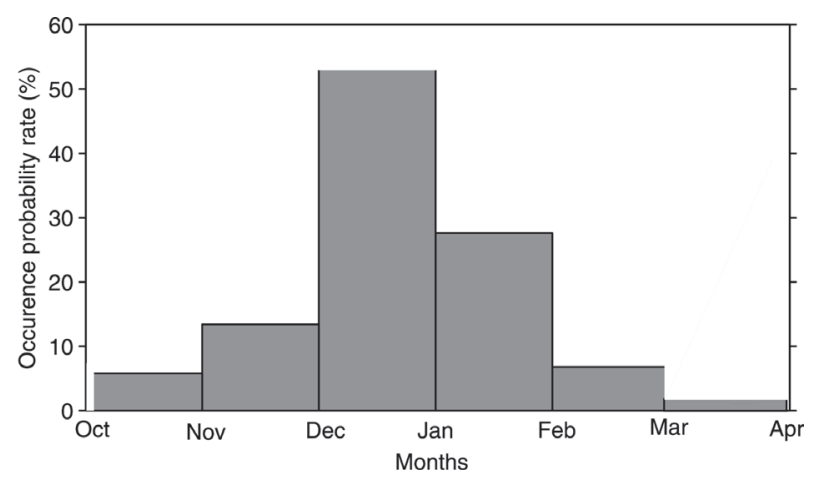

Fig. 5. Histogram represents the SuperDARN-PMSE occurrence probability distribution with initial conditions during summer months. no substantial correlation between the SuperDARN-PMSE rates and the cosmic noise absorption was found. Although auroral particle influence on Zhongshan PMSE could have resulted in the semidiurnal variation as noted by Liu et al. (2013), using Kp index as proxy. This indicates an important technical difference between the Kp index and the riometer noise absorption approach. The Kp index is valued based on global geomagnetic field measurements and thus depends on the electron density above $100 \mathrm{~km}$, whereas cosmic noise absorption is determined by height integrated electron density below $100 \mathrm{~km}$ (Smirnova et al. 2010).

This result agrees with Barabash et al. (2002) whereby there is no significant correlation between PMSE variations and cosmic noise absorption. However, Morris et al. (2005) found a very weak correlation of PMSE, observed by VHF radar, and cosmic noise absorption. This may be attributed to long HF radar wavelength relative to VHF radar wavelengths. At HF, one is observing icy dust particle charging whereas at VHF one is observing electron diffusion, which requires strong density gradient and by extension peak

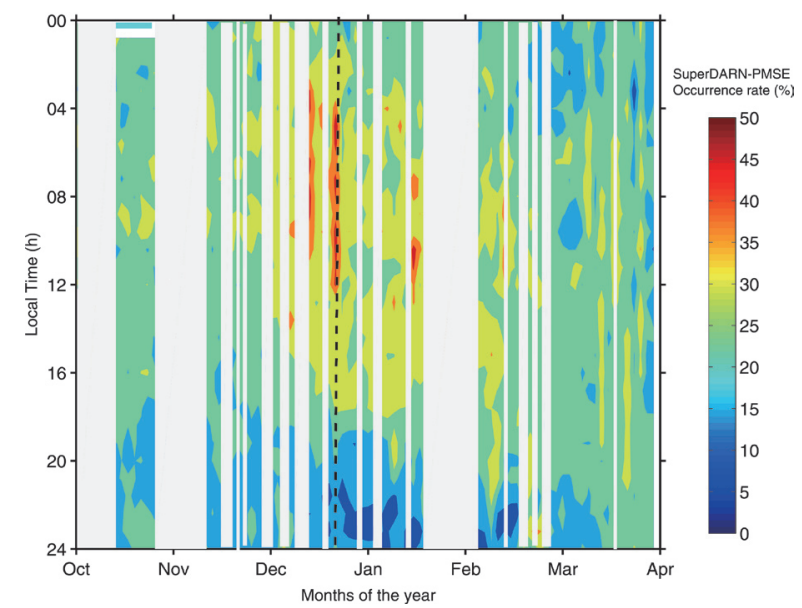

Fig. 4. Same as Fig. 3 but for October 2006 to April 2007 summer season.

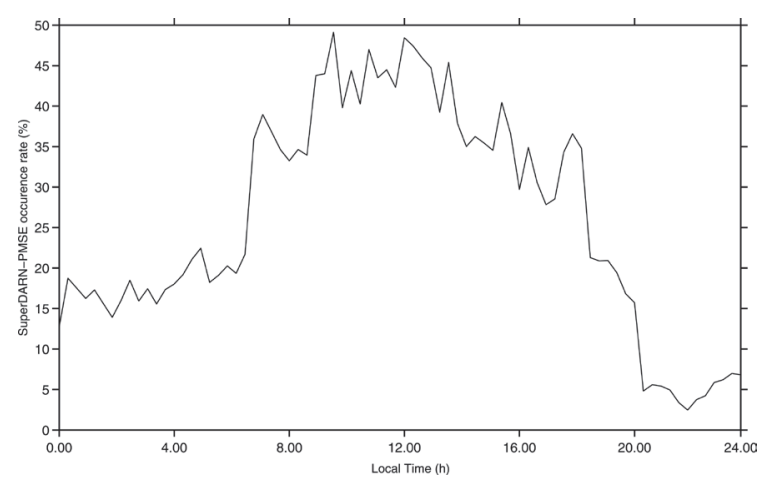

Fig. 6. Mean diurnal SuperDARN-PMSE occurrence over SANAE IV for the year 2005/2006 and year 2006/2007 summers. 
(a)

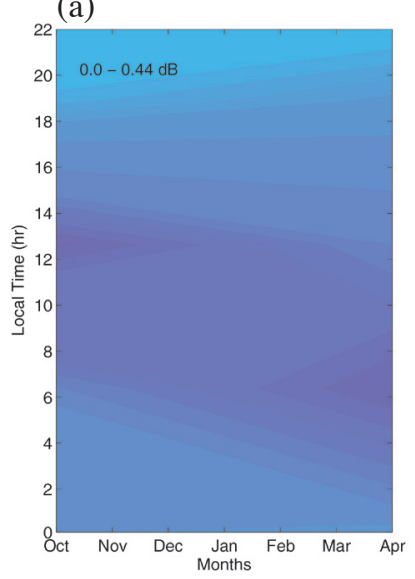

(b)

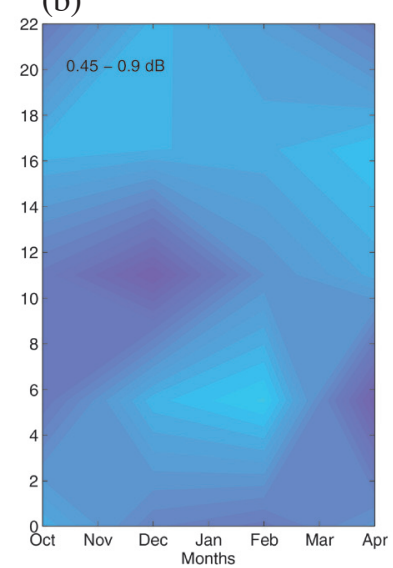

(c)

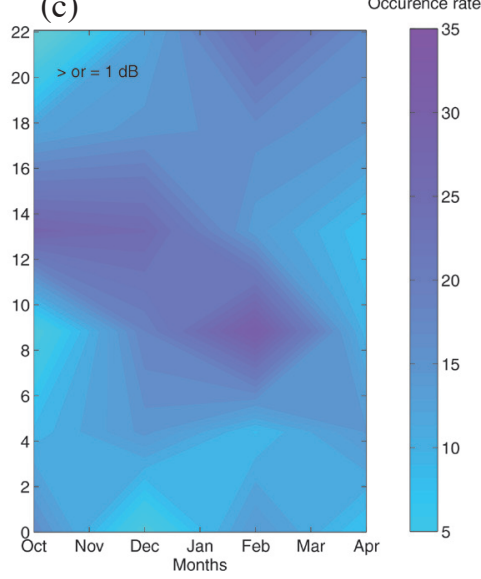

Fig. 7. Diurnal and Seasonal contours for SuperDARN-PMSE at different absorption levels: (a) absorption $=0.0-0.4 \mathrm{~dB}$, (b) absorption $=0.5-0.9 \mathrm{~dB}$, and (c) absorption $\geq 1$ over observational periods.

cosmic absorption. Other factors, such as neutral wind forcing, can also induce significant influence on PMSE over many years.

\subsection{Temperature and Neutral Winds Effect}

To investigate a possible connection between SuperDARN-PMSE and mesospheric temperature we present the SABER vertical temperature average during the SuperDARN-PMSE seasons in Fig. 8. SABER measured $15 \mu \mathrm{m}$ $\mathrm{CO}_{2}$ limb emissions which can be used to estimate the neutral temperatures up to approximately $130 \mathrm{~km}$. In order to maintain a certain temperature in the instrument, SABER obtains profiles from $83^{\circ} \mathrm{S}-52^{\circ} \mathrm{N}$ during its south-looking mode and at every 60 days the view direction switches to an analogous north-looking mode. Here, temperature measurements are retrieved during SABER's south-looking mode. The data were then selected for the vicinity of SANAE IV (i.e., $71 \pm 4^{\circ} \mathrm{S}$ and $2 \pm 10^{\circ} \mathrm{W}$ respectively). We combined temperature measurements for the year 2005/2006 and 2006/2007 SuperDARN-PMSE season. It should be noted that there was no SABER temperature data for the February months as SABER was in north-looking mode. From the figure (Fig. 8) it can be seen that, close to the solstice, there is a lowering of mesopause temperature until January (i.e., 30 days after the summer solstice), whereas in March the vertical temperature starts to increase. Prior to the summer solstice in November, the temperature is found to be approximately $149 \mathrm{~K}$ around mesopause region tied to around $10 \%$ SuperDARN-PMSE occurrence rate (Fig. 5). In December the temperature decreases, reaching about $134 \mathrm{~K}$, while the SuperDARN-PMSE probability rate increases significantly (around 50\%). Unfortunately, temperature measurements were not available in our region of interest in February when the SuperDARN-PMSE rate started decreasing. The temperature for March provides what should be an- ticipated as it increases up to $204 \mathrm{~K}$ with an occurrence rate much lower than the pre-summer solstice. In order to make a quantitative analysis over the potential correlation between the aforementioned parameters, we obtained neutral wind measurements from SuperDARN SANAE IV radar.

SuperDARN radars were basically designed to detect ionospheric backscatter and to study the high-latitude ionosphere dynamics, Greenwald et al. (1995). However, SuperDARN radars also detect echoes from other sources such as meteors. The radar detection of meteor echoes around $94 \mathrm{~km}$ altitude is associated with velocity drift, which can be used to study neutral wind variations. Neutral wind observations with radar may not be a perfect proxy as pointed out by Yukimatu and Tsutumi $(2002,2003)$, as wind velocity is altitude dependent. However, SuperDARN radar may track the neutral wind within $90-94 \mathrm{~km}$, thus provide good information regarding the trend of meridional and zonal winds in relation to SuperDARN-PMSE observed.

Theoretical explanations on how the gravity wave drives meridional circulation from the winter to summer mesosopause is provided by Andrews et al. (1987). This driven circulation results in extremely low temperature at the summer mesopause: a condition necessary for PMSE occurrence. In order to test this theoretical assumption, in relation with SuperDARN-PMSE observation, we investigated the change of meridional and zonal wind components. Further, we want to confirm if our previous analysis implies that the mechanism responsible for SuperDARN-PMSE variations is steady over the long term.

Here we obtained neutral wind radar measurements from the years 2002 - 2007. Figure 9 (top and bottom panels) presents contours of all the available monthly-mean winds. The gap in the figures which covers the early part of 2007 results from data gaps in SuperDARN SANAE IV HF radar. This figure provides a clear indication of how the monthlymean winds vary from year to year. Since the data analysis 
is based on monthly averages, we might ignore the short periodic waves. In both meridional wind (Fig. 9 top) and zonal wind (Fig. 9 bottom) observed over SANAE IV, a seasonal pattern that repeats from year-to-year is evident, at least in summer. It can be seen that prior to the start of the SuperDARN-PMSE peaks (November), the mean summer meridional winds at height $\sim 94 \mathrm{~km}$ become more positive and the zonal winds also grow significantly. On the other hand, the time interval between mid-December until early January, which represent the high peak in SuperDARN-PMSE, we observe a dramatic simultaneous decelerating equator ward meridional winds and starting of westward zonal winds. This period (mid-December to early January) represents the time of high peaks in seasonal SuperDARN-PMSE (Fig. 4). This is similar to the work of Dowdy et al. (2007). According to Dowdy et al. (2007), summer maxima in both the westward and equator ward winds occur closer to the solstice in the Antarctic than in the Arctic. Such greater symmetry around the solstice may be attributed to radiative effects which play a greater role in controlling the state of the Antarctic mesosphere and lower thermosphere (MLT) than in the Arctic, where dynamical effects seems to be more important. Nevertheless, middle atmosphere transport circulation is known to be pole to pole (Andrews et al. 1987); there is rising motion in the summer hemisphere and sinking in the winter hemisphere. In this case, the equator ward circulation will induce cold air (Holton and Alexander 2000; Lübken et al. 2004; Morris et al. 2007; Morris et al. 2009) for the benefit of SuperDARN-PMSE occurrence peaks.

In separate studies over Davis in Antarctica, Morris et al. (2007); Morris et al. (2009) found changes in PMSE modulation in connection with the meridional wind and mesopause temperature structure. In contrast, PMSE study at Andenes (Zeller et al. 2009) shows anti-correlation with temperature during the PMSE season in 2002. During 2002 season, the mesospheric temperature over Andenes was anomalously high and close to the water vapor frost point. The implication is that SuperDARN-PMSE occurrence might truly be more strongly influenced by other factors such as planetary waves. However, adequate temperatures measurements have yet to be acquired at SANAE IV and temperature model parameters are also somewhat subject to ambiguity at sub-auroral locations. At aurora locations conductivity is not certain, the electric field is highly dynamic and the linear coefficient between heating and cooling becomes less realistic. The polar MLT are too low for a total probe using in-situ satellites thus; measurements can only

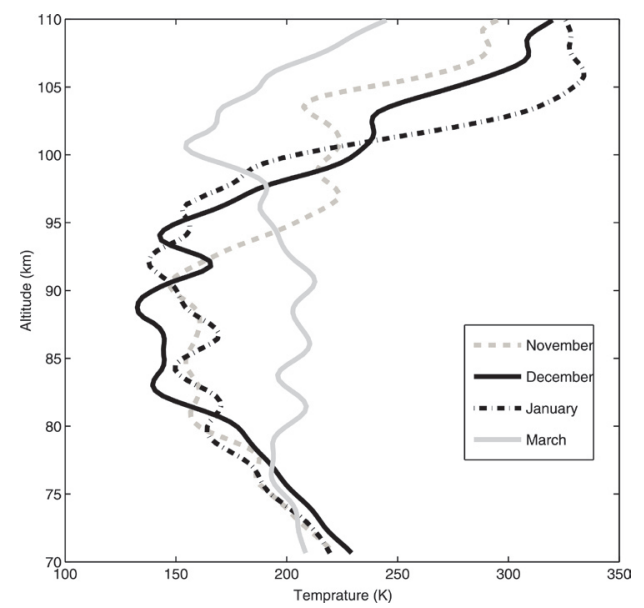

Fig. 8. SABER mean temperature profile for November (dash-gray line), December (thick line), January (dash-dot line), and March (thickgray line) SuperDARN-PMSE season in the vicinity of SANAE IV.
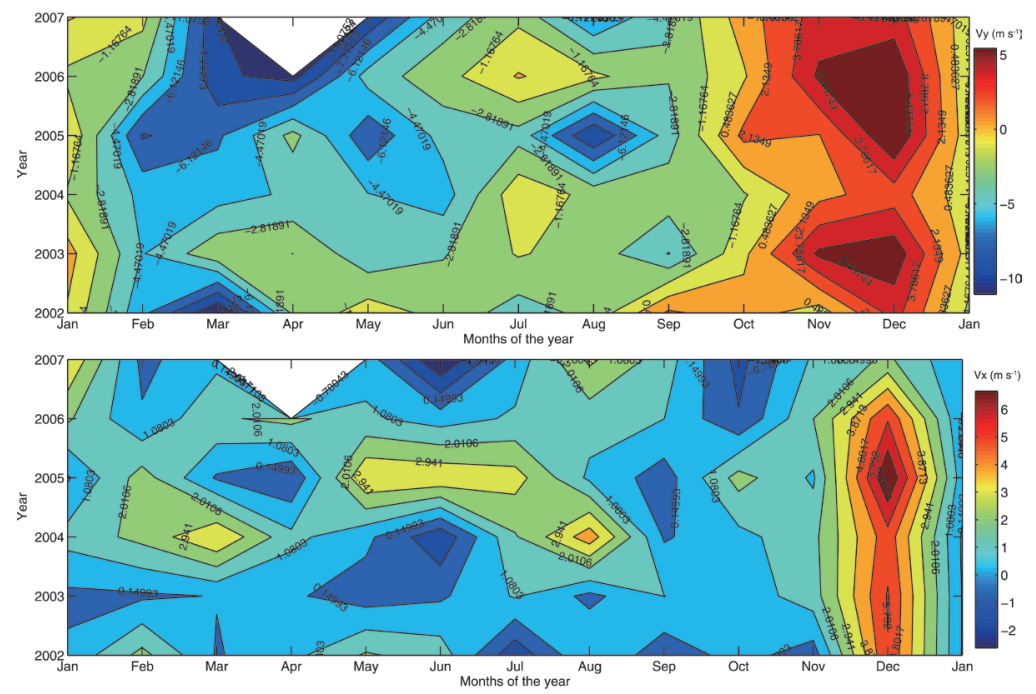

Fig. 9. Contour map of Monthly-variations of meridional (top) and zonal (bottom) mean winds from the year 2002 - 2007. Prior to the summer solstice, mean meridional winds at height $94 \mathrm{~km}$ become more positive and the zonal winds also grow, whereas there is a decelerating equator ward meridional wind and starting of westward zonal winds from December solstice until early January. 
be an estimate. The upcoming ground based LiDAR (Light Detection and Ranging) campaign at SANAE IV may provide a unique opportunity to, fully, study thermal responses including charged ice aerosol particles over SANAE IV. This will complement or modify the present SuperDARNPMSE observation.

\section{CONCLUSIONS}

Using SuperDARN SANAE IV HF radar we observed near range backscatter echoes during the 2005 - 2007 summer periods that cannot be explained by ionospheric or meteor echoes. We proposed SuperDARN-PMSE as the most possible origin of these echoes. Based on the obtained results the following are the noted salient features:

(1) The SuperDARN-PMSE seasonal rate is enhanced at the beginning of December, remains at the highest level until several days after the summer solstice and then gradually decreases towards the end of February.

(2) No interannual variation is seen in the SuperDARNPMSE occurrence probability rates, the maximum rate is $\sim 50 \%$ around the summer solstice.

(3) The SuperDARN-PMSE occurrence on the day-to-day scale show, predominantly, diurnal variation, a broader maximum peak between $12-14$ LT and distinct minimum of $21 \mathrm{LT}$.

(4) We found no significant correlations between the SuperDARN-PMSE occurrence rate and cosmic radio noise absorption. Whereas the seasonal SuperDARN-PMSE variations correlate with the mesopause temperature. The occurrence rate increases with the lowering of neutral temperature.

(5) The seasonal trends for both the meridional winds and zonal winds are very stable from year-to-year hence the SuperDARN-PMSE variability's are reproduced yearby-year. After comparing the relative meridional and zonal winds with temperatures trend we suggest that the pole to pole mesospheric transport circulations probably play an important role in SuperDARN-PMSE occurrence probability rate.

(6) In the future, SuperDARN-PMSE variations can be studied in relation to other dynamic effects. In particular, a long term trend of the effects of gravity waves over SANAE IV will be of great interest to confirm or modify the suggestions in the present study.

Acknowledgements The authors express thanks for the support of South African National Antarctic Program (SANAP) and logistics of South African National Space Agency (SANSA) in providing SANAE IV riometer data. SANAP, SANSA, and HF radar group, University of KwaZulu-Natal support the SANAE IV HF radar. The SuperDARN radar wind data is provided by British Antarctic Survey, UK, at http://psddb.nerc-bas.ac.uk. And the authors also express thanks to the three TAOs Anonymous Reviewers for their valuable comments and suggestions. The SANAE HF radar project is supported through the National Research Foundation (NRF) project under the grand id: 93068.

\section{REFERENCES}

Andrews, D. G., J. R. Holton, and C. B. Leovy, 1987: Middle Atmosphere Dynamics, International Geophysics, Vol. 40, Academic Press, New York, 489 pp.

Balsley, B. B., W. L. Ecklund, and D. C. Fritts, 1983: Mesospheric radar echoes at Poker Flat, Alaska: Evidence for seasonally dependent generation mechanisms. Radio Sci., 18, 1053-1058, doi: 10.1029/RS018i006p01053. [Link]

Barabash, V., S. Kirkwood, and P. B. Chilson, 2002: Are variations in PMSE intensity affected by energetic particle precipitation? Ann. Geophys., 20, 539-545, doi: 10.5194/angeo-20-539-2002. [Link]

Chisham, G., M. Lester, S. E. Milan, M. P. Freeman, W. A. Bristow, A. Grocott, K. A. McWilliams, J. M. Ruohoniemi, T. K. Yeoman, P. L. Dyson, R. A. Greenwald, T. Kikuchi, M. Pinnock, J. P. S. Rash, N. Sato, G. J. Sofko, J. P. Villain, and A. D. M. Walker, 2007: A decade of the Super Dual Auroral Radar Network (SuperDARN): Scientific achievements, new techniques and future directions. Surv. Geophys., 28, 33-109, doi: 10.1007/s10712-007-9017-8. [Link]

Cho, J. Y. N. and J. Röttger, 1997: An updated review of polar mesosphere summer echoes: Observation, theory, and their relationship to noctilucent clouds and subvisible aerosols. J. Geophys. Res., 102, 2001-2020, doi: 10.1029/96JD02030. [Link]

Cho, J. Y. N., M. C. Kelley, and C. J. Heinselman, 1992: Enhancement of Thomson scatter by charged aerosols in the polar mesosphere: Measurements with a 1.29GHz radar. Geophys. Res. Lett., 19, 1097-1100, doi: 10.1029/92GL01155. [Link]

Dowdy, A. J., R. A. Vincent, M. Tsutsumi, K. Igarashi, Y. Murayama, W. Singer, and D. J. Murphy, 2007: Polar mesosphere and lower thermosphere dynamics: 1 . Mean wind and gravity wave climatologies. J. Geophys. Res., 112, D17104, doi: 10.1029/2006JD008126. [Link]

Ecklund, W. L. and B. B. Balsley, 1981: Long-term observations of the Arctic mesosphere with the MST radar at Poker Flat, Alaska. J. Geophys. Res., 86, 7775-7780, doi: 10.1029/JA086iA09p07775. [Link]

Greenwald, R. A., K. B. Baker, J. R. Dudeney, M. Pinnock, T. B. Jones, E. C. Thomas, J. P. Villain, J. Cerister, C. Senior, C. Hanuise, 1995: DARN/SuperDARN: A global view of the dynamics of high-latitude convection. Space Sci. Rev., 71, 761-796, doi: 10.1007/ BF00751350. [Link] 
Hargreaves, J. K. and M. Friedrich, 2003: The estimation of D-region electron densities from riometer data. Ann. Geophys., 21, 603-613, doi: 10.5194/angeo-21603-2003. [Link]

Hervig, M. E., L. L. Gordley, J. M. Russell III, and S. M. Bailey, 2009: SOFIE PMC observations during the northern summer of 2007. J. Atmos. Sol.-Terr. Phys., 71, 331-339, doi: 10.1016/j.jastp.2008.08.010. [Link]

Hoffmann, P., W. Singer, and J. Bremer, 1999: Mean seasonal and diurnal variations of PMSE and winds from 4 years of radar observations at ALOMAR. Geophys. Res.Lett.,26,1525-1528, doi: 10.1029/1999GL900279. [Link]

Holton, J. R. and M. J. Alexander, 2000: The role of waves in the transport circulation of the middle atmosphere. In: Siskind, D. E., S. D. Eckermann, and M. E. Summers (Eds.), Atmospheric Science Across the Stratopause, American Geophysical Union, Washington, D.C., 342 pp, doi: 10.1029/GM123p0021. [Link]

Hosokawa, K., T. Ogawa, A. S. Yukimatu, N. Sato, and T. Iyemori, 2004: Statistics of Antarctic mesospheric echoes observed with the SuperDARN Syowa Radar. Geophys. Res. Lett., 31, L02106, doi: 10.1029/2003GL018776. [Link]

Hosokawa, K., T. Ogawa, N. F. Arnold, M. Lester, N. Sato, and A. S. Yukimatu, 2005: Extraction of polar mesosphere summerechoes from SuperDARN data.Geophys. Res. Lett., 32, L12801, doi: 10.1029/2005GL022788. [Link]

Huaman, M. M. and B. B. Balsley, 1999: Differences in near-mesopause summer winds, temperatures, and water vapor at northern and southern latitudes as possible causal factors for inter-hemispheric PMSE differences. Geophys. Res. Lett., 26, 1529-1532, doi: 10.1029/1999GL900294. [Link]

Hussey, G. C., C. E. Meek, D. André, A. H. Manson, G. J. Sofko, and C. M. Hall, 2000: A comparison of Northern Hemisphere winds using SuperDARN meteor trail and MF radar wind measurements. J. Geophys. Res., 105, 18053-18066, doi: 10.1029/2000JD900272. [Link]

Jarvis, M. J., M. A. Clilverd, M. C. Rose, and S. Rodwell, 2005: Polar mesosphere summer echoes (PMSE) at Halley $\left(76^{\circ} \mathrm{S}, 27^{\circ} \mathrm{W}\right)$, Antarctica. Geophys. Res. Lett., 32, L06816, doi: 10.1029/2004GL021804. [Link]

Kirkwood, S., 1993: Modelling the undisturbed highlatitude E region. Adv. Space Res., 13, 101-104, doi: 10.1016/0273-1177(93)90258-D. [Link]

Klekociuk, A. R., R. J. Morris, and J. L. Innis, 2008: First Southern Hemisphere common-volume measurements of PMC and PMSE. Geophys. Res. Lett., 35, L24804, doi: 10.1029/2008GL035988. [Link]

Klostermeyer, J., 1999: On the diurnal variation of polar mesosphere summer echoes. Geophys. Res. Lett., 26, 3301-3304, doi: 10.1029/1999GL003629. [Link]
Latteck, R., W. Singer, R. J. Morris, W. K. Hocking, D. J. Murphy, D. A. Holdsworth, and N. Swarnalingam, 2008: Similarities and differences in polar mesosphere summer echoes observed in the Arctic and Antarctica. Ann. Geophys., 26, 2795-2806, doi: 10.5194/angeo-26-2795-2008. [Link]

Lester, M., 2013: The Super Dual Auroral Radar Network (SuperDARN): An overview of its development and science. Adv. Polar Sci., 24, 1-11, doi: 10.3724/ SP.J.1085.2013.00001. [Link]

Liu, E. X., H. Q. Hu, K. Hosokawa, R. Y. Liu, Z. S. Wu, and Z. Y. Xing, 2013: First observations of polar mesosphere summer echoes by SuperDARN Zhongshan radar. J. Atmos. Sol.-Terr. Phys., 104, 39-44, doi: 10.1016/j.jastp.2013.07.011. [Link]

Liu, J. Y., C. J. Pan, and C. C. Lee, 2002: VHF radar and MF/ HF dynasonde observations during Polar Mesosphere Summer Echoes conditions at EISCAT. Earth Planets Space, 54, 691-698, doi: 10.1186/BF03351720. [Link]

Lübken, F. J., A. Müllemann, and M. J. Jarvis, 2004: Temperatures and horizontal winds in the Antarctic summer mesosphere. J. Geophys. Res., 109, D24112, doi: 10.1029/2004JD005133. [Link]

Morris, R. J., D. J. Murphy, I. M. Reid, D. A. Holdsworth, and R. A. Vincent, 2004: First polar mesosphere summer echoes observed at Davis, Antarctica $\left(68.6^{\circ} \mathrm{S}\right)$. Geophys. Res. Lett., 31, L16111, doi: 10.1029/2004GL020352. [Link]

Morris, R. J., M. B. Terkildsen, D. A. Holdsworth, and M. R. Hyde, 2005: Is there a causal relationship between cosmic noise absorption and PMSE? Geophys. Res. Lett., 32, L24809, doi: 10.1029/2005GL024568. [Link]

Morris, R. J., D. J. Murphy, A. R. Klekociuk, and D. A. Holdsworth, 2007: First complete season of PMSE observations above Davis, Antarctica, and their relation to winds and temperatures. Geophys. Res. Lett., 34, L05805, doi: 10.1029/2006GL028641. [Link]

Morris, R. J., A. R. Klekociuk, R. Latteck, W. Singer, D. A. Holdsworth, and D. J. Murphy, 2009: Inter-hemispheric asymmetry in polar mesosphere summer echoes and temperature at $69^{\circ}$ latitude. J. Atmos. Sol.-Terr. Phys., 71, 464-469, doi: 10.1016/j.jastp.2008.09.042. [Link]

Ogawa, T., S. Nozawa, M. Tsutsumi, N. F. Arnold, N. Nishitani, N. Sato, and A. S. Yukimatu, 2004: Arctic and Antarctic polar mesosphere summer echoes observed with oblique incidence HF radars: Analysis using simultaneous MF and VHF radar data. Ann. Geophys., 22, 40494059, doi: 10.5194/angeo-22-4049-2004. [Link]

Ogunjobi, O., V. Sivakumar, and N. Mbatha, 2014a: A case study of energy deposition and absorption by magnetic cloud electrons and protons over the high latitude stations: Effects on the mesosphere and lower thermosphere. Terr. Atmos. Ocean. Sci., 25, 219-232, doi: 10.3319/TAO.2013.10.14.01(AA). [Link] 
Ogunjobi, O., V. Sivakumar, and W. T. Sivla, 2014b: A superposed epoch study of the effects of solar wind stream interface events on the upper mesospheric and lower thermospheric temperature. Adv. Space Res., 54, 1732-1742, doi: 10.1016/j.asr.2014.07.005. [Link]

Palmer, J. R., H. Rishbeth, G. O. L. Jones, and P. J. S. Williams, 1996: A statistical study of polar mesosphere summer echoes observed by EISCAT. J. Atmos. Terr. Phys., 58,307-315, doi: 10.1016/0021-9169(95)000380 . [Link]

Rapp, M. and F. J. Lübken, 2004: Polar mesosphere summer echoes (PMSE): Review of observations and current understanding. Atmos. Chem. Phys., 4, 4777-4876, doi: 10.5194/acpd-4-4777-2004. [Link]

Richardson, I. G., E. W. Cliver, and H. V. Cane, 2001: Sources of geomagnetic storms for solar minimum and maximum conditions during 1972-2000. Geophys. Res. Lett., 28, 2569-2572, doi: 10.1029/2001GL013052. [Link]

Röttger, J., 1994: Polar mesosphere summer echoes: Dynamics and aeronomy of the mesosphere. Adv. Space Res., 14, 123-137, doi: 10.1016/0273-1177(94)901252. [Link]

Smirnova, M., E. Belova, S. Kirkwood, and N. Mitchell, 2010: Polar mesosphere summer echoes with ESRAD, Kiruna, Sweden: Variations and trends over 19972008. J. Atmos. Sol.-Terr. Phys., 72, 435-447, doi: 10.1016/j.jastp.2009.12.014. [Link]

Wilson, A. and P. H. Stoker, 2002: Imaging riometer ob- servations on energetic electron precipitation at SANAE IV, Antarctica. J. Geophys. Res., 107, doi: 10.1029/2000JA000463. [Link]

Wu, C. C., N. Gopalswamy, R. P. Lepping, and S. Yashiro, 2013: Characteristics of magnetic clouds and interplanetary coronal mass ejections which cause intense geomagnetic storms. Terr. Atmos. Ocean. Sci., 24, 233241, doi: 10.3319/TAO.2012.09.26.03(SEC). [Link]

Yukimatu, A. S. and M. Tsutsumi, 2002: A new SuperDARN meteor wind measurement: Raw time series analysis method and its application to mesopause region dynamics. Geophys. Res. Lett., 29, doi: 10.1029/2002GL015210. [Link]

Yukimatu, A. S. and M. Tsutsumi, 2003: Correction to "A new SuperDARN meteor wind measurement: Raw time series analysis method and its application to mesopause region dynamics" by Akira Sessai Yukimatu and Masaki Tsutsumi. Geophys. Res. Lett., 30, doi: 10.1029/2002GL016560. [Link]

Zeller, O., P. Hoffmann, J. Bremer, and W. Singer, 2009: Mesosphere summer echoes, temperature, and meridional wind variations at mid- and polar latitudes. $J$. Atmos. Sol.-Terr. Phys., 71, 931-942, doi: 10.1016/j. jastp.2009.03.013. [Link]

Zhang, Y., L. J. Paxton, and H. Kil, 2013: Multi-periodic auroral and thermospheric variations in 2006. Terr. Atmos. Ocean. Sci., 24, 207-212, doi: 10.3319/ TAO.2012.09.20.01(SEC). [Link] 